\author{
Chenchen Shao · Yoichi Suzuki · Fumiaki Kamada \\ Kiyoshi Kanno · Mayumi Tamari · Koichi Hasegawa \\ Yoko Aoki - Shigeo Kure · Xue Yang · Hiroko Endo \\ Reiko Takayanagi · Chifuyu Nakazawa \\ Toshio Morikawa $\cdot$ Miki Morikawa \\ Shigeaki Miyabayashi · Yasushi Chiba \\ Minoru Karahashi · Seichi Saito · Gen Tamura \\ Taro Shirakawa $\cdot$ Yoichi Matsubara
}

\title{
Linkage and association of childhood asthma with the chromosome 12 genes
}

Received: 1 September 2003 / Accepted: 19 November 2003/Published online: 7 February 2004

(C) The Japan Society of Human Genetics and Springer-Verlag 2004

\begin{abstract}
Several studies have shown linkage of chromosome region 12q13-24 to bronchial asthma and related phenotypes in ethnically diverse populations. In the Japanese population, a genome-wide study failed
\end{abstract}

C. Shao $\cdot$ Y. Suzuki $(\bowtie) \cdot$ F. Kamada $\cdot$ K. Kanno $\cdot$ Y. Aoki

S. Kure $\cdot$ X. Yang $\cdot$ Y. Matsubara

Department of Medical Genetics,

Tohoku University School of Medicine,

1-1 Seiryo-machi, Aoba-ku, Sendai 980-8574, Japan

E-mail: ysuzuki@mail.tains.tohoku.ac.jp

Tel.: + 81-22-7178140

Fax: $+81-22-7178142$

C. Shao $\cdot$ G. Tamura

Department of Respiratory and Infectious Diseases,

Tohoku University School of Medicine, Sendai, Japan

M. Tamari · K. Hasegawa · T. Shirakawa

Laboratory for Genetics of Allergic Diseases,

SNP Research Center, The Institute of Physical and Chemical

Research (RIKEN), Yokohama, Japan

H. Endo $\cdot$ R. Takayanagi $\cdot$ C. Nakazawa

Department of Pediatrics, Tohoku Rosai Hospital, Sendai, Japan

T. Morikawa

Morikawa Children's Clinic, Sendai, Japan

M. Morikawa

Department of Pediatrics, JR Sendai Hospital, Sendai, Japan

S. Miyabayashi

Department of Pediatrics, Sendai National Hospital, Sendai, Japan

Y. Chiba

Depatment of Pediatrics, Japanese Red Cross Sendai Hospital,

Sendai, Japan

M. Karahashi

Karahashi Children's Clinic, Sendai, Japan

S. Saito

Department of Pediatrics, Funayama Hospital, Yonezawa, Japan

T. Shirakawa

Department of Health Promotion and Human Behavior,

Kyoto University School of Public Health, Kyoto, Japan to show strong evidence of linkage of this region. Chromosome 12 genes that showed association with the disease in at least one report include: the signal transducer and activator of transcription 6 gene (STAT6), the nitrogen oxide synthetase 1 gene (NOS1), the interferon $\gamma$ gene $(I F N G)$, and the activation-induced cytidine deaminase gene $(A I C D A)$. To evaluate the linkage between chromosome 12 and childhood asthma in the Japanese population, we performed sib-pair linkage analysis on childhood asthma families using 18 microsatellite markers on chromosome 12. To investigate association between chromosome 12 candidate genes and asthma, distributions of alleles and genotypes of repeat polymorphisms of STAT6, NOSI, and IFNG were compared between controls and patients. Single nucleotide polymorphism of AICDA was also investigated. Chromosome region 12q24.23-q24.33 showed suggestive linkage to asthma. The NOS1 intron 2 GT repeat and STAT6 exon 1 GT repeat were associated with asthma. Neither the IFNG intron $1 \mathrm{CA}$ repeat nor $465 \mathrm{C} / \mathrm{T}$ of $A I C D A$ showed any association with asthma. Our results suggest that NOS1 and STAT6 are asthmasusceptibility genes and that chromosome region 12q24.23-q24.33 contains other susceptibility gene(s).

Keywords Childhood asthma - Linkage - Association · Polymorphism · NOS1 1 STAT6 $\cdot$ IFNG $\cdot$ AICDA

\section{Introduction}

Bronchial asthma is an inflammatory disease of the airways characterized by airway obstruction and increased airway responsiveness. Asthma is an etiologically complex disease and develops by the interaction of multiple genes and environmental factors. Genome-wide 
linkage studies have identified a number of autosomal regions providing evidence of linkage to asthma, atopy, eosinophilia, and/or other associated phenotypes (CSGA 1997; Daniels et al. 1996; Dizier et al. 2000; Haagerup et al. 2002; Hakonarson et al. 2002; Laitinen et al. 2001; Ober et al. 2000; Wjst et al. 1999; Xu et al. 2001a; Xu et al. 2000; Xu et al. 2001b; Yokouchi et al. 2000). Some of these studies (CSGA 1997; Dizier et al. 2000; Haagerup et al. 2002; Wjst et al. 1999; $\mathrm{Xu}$ et al. 2001a; Xu et al. 2000; Yokouchi et al. 2000) and those focused on a single chromosome (Barnes et al. 1999; Barnes et al. 1996; Kruglyak et al. 1996; Malerba et al. 2000; Nickel et al. 1997; Wilkinson et al. 1998; Raby et al. 2003) suggested linkage of chromosome 12q regions to asthma or related phenotypes in diverse populations.

In a genome-wide linkage analysis of mite-sensitive Japanese childhood asthma, the $110-145 \mathrm{cM}$ region from the pter (the telomere of the short arm) showed maximum logarithm of odds score (MLS) more than 1.0 with the highest MLS of 1.92 at $111.9-125.3 \mathrm{cM}$ (Yokouchi et al. 2000). The highest MLS did not reach the value of "significant" (MLS=3.6) or "suggestive" $(\mathrm{MLS}=2.2)$ linkage to the disease (Lander and Kruglyak 1995). The region in which MLS exceeded 1.0 was roughly overlapped by those of studies on Afro-Caribbean, French, and British populations (Barnes et al. 1996; Dizier et al. 2000; Wilkinson et al. 1998). To establish the linkage between asthma and chromosome 12 region, evidence of the suggestive linkage must be replicated using a different set of samples from the same population (Lander and Kruglyak 1995).

Candidate genes of chromosome 12q15-q24 include the signal transducer and activator of transcription 6 gene (STAT6), interferon- $\gamma(I F N G)$, stem cell factor $(S F C)$, leukotriene A4 hydrolase $(L T A 4 H)$, insulin-like growth factor (IGF1), $\beta$-subunit of nuclear factor-Y $(N F Y B)$, B-cell translocation gene $1(B T G 1)$, and nitrogen oxide synthetase 1 (NOS1) (Barnes et al. 1996; Dizier et al. 2000; Wjst et al. 1999). Of these, STAT6, NOSI, and IFNG were investigated with case-control studies and showed positive association with asthma in at least one study. Gao et al. (2000b) demonstrated the association of the single nucleotide polymorphism (SNP) $2964 \mathrm{G} / \mathrm{A}$ of STAT6 with adult asthma in Japanese populations. However, this association was not replicated in later studies on German/Swedish (Duetsch et al. 2002) or Japanese populations (Tamura et al. 2001). Instead, a GT repeat polymorphism in exon 1 was associated with eosinophil count in the German/Swedish study and with allergic diseases in the Japanese study. A dinucleotide repeat marker in NOS1 was also reported to be associated with the disease in the British population (Gao et al. 2000a). An association between a SNP in NOS1 and eosinophil count was also shown in German/ Swedish patients (Immervoll et al. 2001). Hyden et al. (1997) reported that no polymorphism in the IFNG was associated with atopic asthma, whereas an association between the GT repeat in intron 1 of IFNG and childhood asthma was suggested in the Japanese population (Nakao et al. 2001). Heinzmann et al. (2000a) screened polymorphisms in SCF, STAT6, TR2 (thyroid receptor 2), and $L T A 4 H$ and found two polymorphisms in $S C F$ and one in TR2 in the German population. They found no evidence of linkage or association of these genes with atopy.

All of the above-mentioned studies were based on case-control design. On the other hand, using the transmission disequilibrium test (TDT), Noguchi et al. (2001) reported that the activation-induced cytidine deaminase gene $(A I C D A)$ was associated with childhood asthma in the Japanese population. The AICDA gene is located in the short arm of chromosome 12, where linkage has never been suggested. They selected this gene as a candidate gene for asthma because deficiency of $A I C D A$ resulted in low IgE production, thereby the variations of the gene might be responsive to atopy. More recently, Isidoro-García et al. (2003) reported a case-control study on the same SNP of AICDA gene in the Spanish population. They failed to show the association of this SNP with the disease.

Among candidate genes of chromosome region 12q15-q24, STAT6, IFNG, and NOS1 have been suggested to be associated with asthma in at least one study. Although the locus was not a suspected linkage to asthma, the AICDA gene showed a positive result in one study. As often seen in genetic analyses of a complex disease (Ioannidis et al. 2001), inconsistencies were noticed between the studies of chromosome 12 candidate genes for asthma. Studying other sets of samples in the same population is necessary to conclude whether a particular gene is truly associated with this complex disease.

In the present study, we investigated linkage of markers on chromosome 12 to childhood asthma in the Japanese population. We also investigated association of four candidate genes, AIDCA, STAT6, NOS1, and $I F N G$, with Japanese childhood asthma.

\section{Materials and methods}

Families and individuals

For linkage analysis, 18 families with affected sib pairs and one family with an affected sib trio were recruited. For the association study, 184 controls and 115 patients were genotyped. One hundred control subjects were selected in the Osaka area, Japan, as previously described (Heinzmann et al. 2000b; Mao et al. 1996), and 84 controls were selected from adult staff and student volunteers from Tohoku University School of Medicine in Sendai, Japan. Individuals with a history of treatment for asthma or eczema were excluded from controls. Forty-two patients were diagnosed at hospitals in the Sendai area, which included patients from 19 families for linkage analysis. For an association study, one patient per family was selected. Other patients were recruited as described (Heinzmann et al. 2000b; Mao et al. 1996). None of the samples were previously analyzed for chromosome 12 linkage markers, NOS1, IFNG, STAT6, or AICDA. Diagnosis of asthma of probands was made by pediatricians specializing in allergic diseases. 
The criteria of asthma were two or more episodes of wheezing and shortness of breath and reversibility of the wheezing and dyspnea, either spontaneously or by bronchodilator treatment. The definition of "childhood" asthma was asthma with onset before age 15 years. Diagnosis of other family members was based on the modified ATS-DLD questionnaire (Ferris 1978). Total serum IgE was regarded as high when the level was $250 \mathrm{IU} / \mathrm{ml}$ or higher. The specific IgE against house dust mite [Dermatophagoides pteronyssinus (Dp)] was judged positive when the RAST score against Dp was $2\left(0.70 \mathrm{U}_{\mathrm{A}} / \mathrm{ml}\right)$ or higher. "Atopy" was defined as either having high total IgE and/or positive Dp-specific IgE. Eighteen families had an affected sibpair and one family had an affected sib trio. All patients with childhood asthma were atopic. All affected sibs and their parents were genotyped.

This study was approved by the ethics committee of Tohoku University School of Medicine.

\section{Genotyping}

DNA was extracted from peripheral blood leukocytes using the Genomic DNA purification kit (Promega, Madison, WI, USA). Chromosome 12 microsatellite markers of the Human GenePairs Primers version 9 (Invitrogen, Carlsland, CA, USA) were used for the linkage analysis. The 18 markers genotyped in this study are shown in Table 1. Information on marker order and position was obtained from LDB2000: Sequence-based Integrated Maps of the Human Genome (http://cedar.genetics.soton.ac.uk/public html/ LDB2000.html) (Wilkinson et al. 1998). The location of $\overline{A I C D A}$ was not cited in this database and was estimated using the NCBI Human Map Viewer.

In chromosome 12 microsatellite marker analyses, PCR mixtures contained $10 \mathrm{mM}$ Tris $/ \mathrm{HCl}, \mathrm{pH} 9.0,50 \mathrm{mM} \mathrm{KCl}, 1.5 \mathrm{mM}$ $\mathrm{MgCl}_{2}, 0.1 \%$ Triton $\mathrm{X}-100,200 \mu \mathrm{M}$ each of deoxynucleotide triphosphate (dNTPs), 0.25 U of rTaq DNA polymerase (TAKARA, Tokyo, Japan), $5 \mu \mathrm{M}$ of each primer, and $10 \mathrm{ng}$ of template DNA in a total volume of $10 \mu \mathrm{l}$. The cycle conditions were $94^{\circ} \mathrm{C}$ for $3 \mathrm{~min}$, followed by 30 cycles of $94^{\circ} \mathrm{C}$ for $45 \mathrm{~s}, 57^{\circ} \mathrm{C}$ for $45 \mathrm{~s}$, and $72^{\circ} \mathrm{C}$ for $1 \mathrm{~min}$, with a final extension of $72^{\circ} \mathrm{C}$ for $10 \mathrm{~min}$. The size of the PCR products was estimated using a 373XL DNA sequencer

Table 1 Map locations for chromosome 12 markers and genes

\begin{tabular}{lrlrrr}
\hline Locus & $\begin{array}{l}\text { Kb from } \\
\text { pter }\end{array}$ & Band & $\begin{array}{l}\text { Male } \\
\text { cM }\end{array}$ & $\begin{array}{l}\text { Female } \\
\text { cM }\end{array}$ & \multicolumn{1}{l}{$\begin{array}{l}\text { Averaged } \\
\text { cM }\end{array}$} \\
\hline ptr & 0 & p13.33 & 0.0 & 0.0 & 0.0 \\
D12S372 & 3761 & p13.33 & 7.5 & 2.5 & 5.0 \\
AICDA & 8468 & p13.31 & 20.0 & 9.3 & 14.7 \\
GATA49D12 & 8513 & p13.31 & 20.1 & 9.4 & 14.7 \\
D12S391 & 13246 & p13.2 & 26.1 & 21.4 & 23.8 \\
D12S373 & 18347 & p12.3 & 32.8 & 35.5 & 34.1 \\
D12S1042 & 28440 & p11.23 & 36.9 & 56.2 & 46.5 \\
cen & 39000 & q11 & 38.7 & 65.0 & 51.9 \\
D12S1301 & 46378 & q12 & 39.7 & 71.3 & 55.5 \\
D12S398 & 56808 & q13.13 & 44.4 & 87.0 & 65.7 \\
STAT6 & 61349 & q13.13 & 45.9 & 92.5 & 69.2 \\
D12S1294 & 73218 & q14.2 & 50.4 & 97.7 & 74.0 \\
IFNG & 73860 & q14.2 & 51.7 & 100.3 & 76.0 \\
D12S375 & 74485 & q14.3 & 52.7 & 103.0 & 77.8 \\
D12S1052 & 80438 & q15 & 57.1 & 106.9 & 82.0 \\
D12S1064 & 96885 & q21.33 & 67.2 & 120.5 & 93.8 \\
D12S1300 & 105918 & q23.1 & 69.8 & 133.1 & 101.4 \\
PAH & 111421 & q23.3 & 73.5 & 143.5 & 108.5 \\
D12S2070 & 125845 & q24.22 & 81.8 & 167.6 & 124.7 \\
NOS1 & 127541 & q24.22 & 82.8 & 174.6 & 128.7 \\
D12S395 & 130349 & q24.23 & 84.1 & 184.3 & 134.2 \\
D12S392 & 138666 & q24.32 & 91.9 & 200.3 & 146.1 \\
D12S2078 & 140437 & q24.33 & 98.1 & 201.8 & 149.9 \\
D12S1045 & 143552 & q24.33 & 110.7 & 212.9 & 161.8 \\
qtr & 146025 & qtr & 119.2 & 218.4 & 168.8 \\
\hline & & & & & \\
\hline
\end{tabular}

(Applied Biosystems, Foster City, CA, USA). GeneScan 500XL TAMRA labeled standard (Applied Biosystems) was used for estimation of fragment lengths.

Primers for the NOS1 intron 2 GT repeat were as described previously (Gao et al. 2000a). One of the primers, 5'ATAGAGCCTGTGCTGAGCCTTC, was 6-FAM labeled. The PCR mixture contained $10 \mathrm{mM}$ Tris $/ \mathrm{HCl}, \mathrm{pH} 9.0,50 \mathrm{mM} \mathrm{KCl}, 1.5 \mathrm{mM}$ $\mathrm{MgCl}_{2}, 0.1 \%$ Triton X-100, $250 \mu \mathrm{M}$ each of dNTPs, $0.5 \mathrm{U}$ of rTaq DNA polymerase, $200 \mu \mathrm{M}$ of each primer, and $10 \mathrm{ng}$ of template DNA in a total volume of $15 \mu \mathrm{l}$. The cycle conditions were $94^{\circ} \mathrm{C}$ for $3 \mathrm{~min}$, followed by 30 cycles of $94^{\circ} \mathrm{C}$ for $30 \mathrm{~s}, 57^{\circ} \mathrm{C}$ for $30 \mathrm{~s}$, and $72^{\circ} \mathrm{C}$ for $40 \mathrm{~s}$, with a final extension of $72^{\circ} \mathrm{C}$ for $10 \mathrm{~min}$.

The primers for the STAT6 exon 1 GT repeat were 5'-GGAGAAGCCGGAAACAGCGG and 5'-GTTCAAGGCTGGCCCTGCTAGC (6-FAM labeled). The PCR mixture was the same as for of NOS1. The cycle conditions were $94^{\circ} \mathrm{C}$ for $3 \mathrm{~min}$, followed by 30 cycles of $94^{\circ} \mathrm{C}$ for $45 \mathrm{~s}, 57^{\circ} \mathrm{C}$ for $45 \mathrm{~s}$, and $72^{\circ} \mathrm{C}$ for $1 \mathrm{~min}$, with a final extension of $72^{\circ} \mathrm{C}$ for $10 \mathrm{~min}$.

Primers for the IFNG intron 2 CA repeat were as previously described (Nakao et al. 2001). The PCR mixture was the same as for $N O S 1$, except that $0.25 \mathrm{U}$ of rTaq and $600 \mu \mathrm{M}$ of each primer were used. The cycle conditions were $95^{\circ} \mathrm{C}$ for $5 \mathrm{~min}$, followed by 25-34 cycles of $95^{\circ} \mathrm{C}$ for $30 \mathrm{~s}, 56^{\circ} \mathrm{C}$ for $30 \mathrm{~s}$, and $72^{\circ} \mathrm{C}$ for $1 \mathrm{~min}$, with a final extension of $72^{\circ} \mathrm{C}$ for 5 min.

The 467C/T (His 155His) polymorphism of AICDA (GeneBank AB040430) was the same polymorphism reported by Noguchi et al. (2001), where they designated this polymorphism as $7888 \mathrm{C} / \mathrm{T}$. This was genotyped using a modified TaqMan PCR method employing allele-specific amplification (Fujii et al. 2000). The common forward primer was 5'-GGCCCCGAGGAAATGAGAAAAT. The reverse primers were 5'-TCCCAGGCTTTGAAAGTTCTTTAG for the C allele and 5'-TCCCAGGCTTTGAAAGTTCTTTGA for the $\mathrm{T}$ allele. The TaqMan probe was 5'-FAM-AGAAGACAGTTCAGGTTCCAAATCGAGG- TAMRA -3'. The PCR mixture contained $7.5 \mu \mathrm{l}$ of $2 \mathrm{X}$ TaqMan Universal PCR Master Mix (Applied Biosystems), $400 \mu \mathrm{M}$ of each PCR primer, $0.12 \mu \mathrm{M}$ of TaqMan probe, and $5 \mathrm{ng}$ of template DNA in a final volume of $15 \mu \mathrm{l}$. The cycle conditions were $50^{\circ} \mathrm{C}$ for $2 \mathrm{~min}, 95^{\circ} \mathrm{C}$ for $3 \mathrm{~min}$, followed by 45 cycles of $95^{\circ} \mathrm{C}$ for $15 \mathrm{~s}$ and $60^{\circ} \mathrm{C}$ for $1 \mathrm{~min}$.

Statistical analysis

Allele frequencies of microsatellite markers were estimated from the parental chromosomes. All chromosome 12 markers were assessed by PEDCHECK (version 1.0) (O'Connell et al. 1998) for pedigree inconsistencies. There was no genotype inconsistency at any loci in all the families. Multipoint linkage analysis was conducted using GENEHUNTER 2 (Kruglyak et al. 1996). For score calculations of the sib trio, we used "all independent pairs of affected/phenotyped sibs" option of the GENEHUNTER 2 program where one sib trio yielded two pairs. In all allelic and genotypic distribution analyses, Fisher's exact $P$ values were calculated using SPSS for Windows version 11.0 J (SPSS Japan, Japan). For multiallelic markers, the $P$ value of association with the disease of each allele or genotype was multiplied by the number of the alleles or genotypes to compensate for multiple testing and expressed as $P c$. The level of significance for the association studies was set at $P(P c)=0.05$.

\section{Results}

Linkage analysis of chromosome 12

Thirty-nine sibs with childhood asthma used for the linkage analysis consisted of 20 males and 19 females. Ages of the patients ranged from 1 to 14 years with the average age of 7.3 years. All affected sibs were positive 

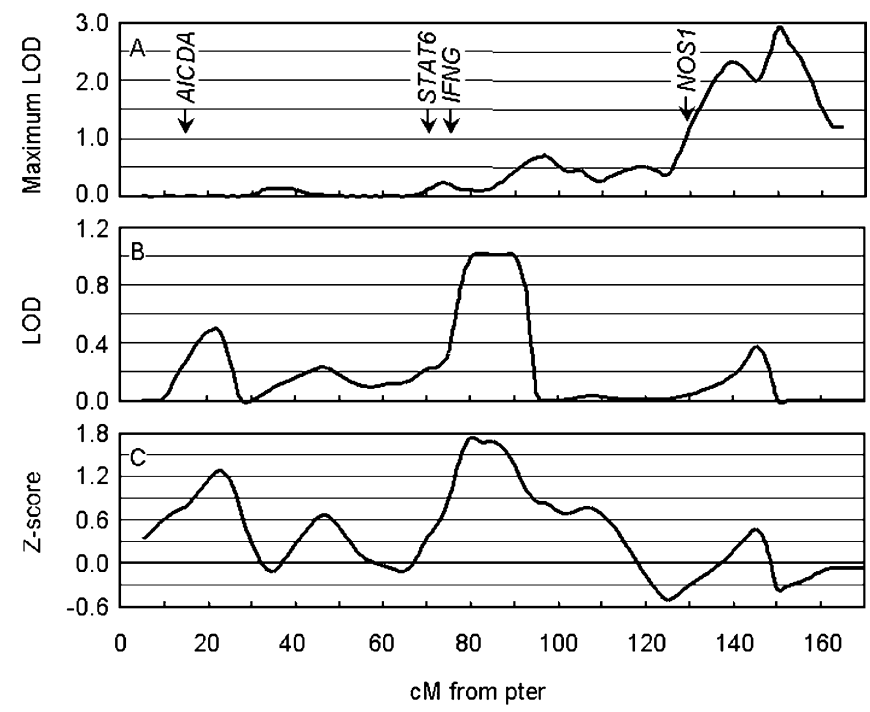

Fig. 1A-C Linkage results for asthma and total IgE level. All calculations were performed by GENEHUNTER 2. A Multipoint maximum likelihood (ML) estimate of identity by decent sharing for asthma affection status. B ML quantitative locus (QTL) variance estimation for $\log _{10}$ (total $\mathrm{IgE}$ level). ML QTL variance estimation (Kruglyak and Lander 1995) is performed instead of traditional Haseman-Elston (HE) QTL analysis because the values calculated with HE QTL analysis were affected by selection of sib pairs from the sib trio. C Nonparametric QTL analysis (Kruglyak and Lander 1995) for $\log _{10}$ (total IgE level)

for Dp-specific IgE. Thirty also showed atopic dermatitis. Results of the linkage analysis of the 18 microsatellite markers of chromosome 12 are shown in Fig. 1. A broad region from $135 \mathrm{cM}$ to $160 \mathrm{cM}$ exceeded 1.5 in MLS (Fig. 1A). Two peaks at 140 and $150 \mathrm{cM}$ were observed, and the latter peak showed a MLS of 2.92, greater than the suggestive linkage level (Lander and Kruglyak 1995). Serum total IgE levels were $\log _{10}$ transformed and subjected to sib-pair quantitative locus (QTL) analysis. The result of maximum likelihood (ML) QTL variance estimation is shown in Fig. 1B. ML QTL variance estimation (Kruglyak and Lander 1995) was performed instead of the traditional Haseman-Elston (HE) QTL analysis, because the values with HE QTL analysis were affected greatly by the selection method of pairs from the sib trio. The highest peak of logarithm of odds $($ LOD) score $(\max =1.02)$ was observed at $83 \mathrm{cM}$. No significant peaks were observed where linkage to asthma was observed. Nonparametric QTL analysis (Kruglyak and Lander 1995) showed the highest peak to be at $80 \mathrm{cM}$ with a Z-score of $1.74(P=0.082)$ (Fig. $1 \mathrm{C})$. The results of QTL analyses did not suggest evidence of QTL for $\log _{10}$ (total IgE level) on chromosome 12 .

\section{Association studies of genes on chromosome 12}

Results of the case-control studies of chromosome 12 candidate genes are shown in Table 2. There were four types of alleles for the GT repeat of exon 1 of STAT6 with the repeat number varying from 13 to 16 in our entire series. Comparison of allele frequencies between patients and controls showed a significant difference in the whole-allele distribution $(P=0.0054)$. This difference was primarily derived from the difference in the frequency of allele 3 (15 repeats). The frequency of this allele was significantly lower in the patients $(P c=0.0044$, odds ratio $(\mathrm{OR})=0.71,95 \%$ confidence interval $(95 \% \mathrm{CI})=0.58-0.87)$. Other alleles did not show difference in frequency between controls and patients. Seven genotypes of this GT repeat were observed. The genotypic distribution differed between patients and controls $(P=0.0054)$. Homozygotes for allele 3 had a lower risk of asthma $(P c=0.0035, \quad \mathrm{OR}=0.718$, $95 \% \mathrm{CI}=0.60-0.86$ ).

We identified six alleles in the GT repeat polymorphism of intron 2 of NOS1 (Table 2). The whole-allele distribution of this polymorphism of patients was significantly different from that of controls $(P=0.0082)$. This difference was primarily due to the difference in frequency of allele 3 (16 repeats) $(P c=0.049, \mathrm{OR}=0.75$, $95 \% \mathrm{CI}=0.60-0.93)$. Eleven genotypes of this GT repeat were observed. The whole genotypic distribution differed between patients and controls $(P=0.0019)$. Homozygotes for allele 3 had a lower risk for asthma than the other genotypes $(P c=0.030, \mathrm{OR}=0.53,95 \% \mathrm{CI}=0.33$ $0.84)$. There was a significant difference in the frequency of heterozygote for allele $4 / 5$ between controls and patients $(P c=0.028)$. The numbers of this genotype is small (zero in controls and six in patients), and its biological meaning is difficult to interpret.

Association of asthma was also tested for the CA repeat of the interferon $\gamma$ gene $(I F N G)$. We identified seven allele types and 16 genotypes of this polymorphism in the Japanese population (Table 2). There was no evidence of association between this polymorphism and asthma in our series.

We also investigated the SNP $465 \mathrm{C} / \mathrm{T}$ of $A I C D A$. Frequencies of the major allele were almost the same between controls and patients. Genotype distribution of controls was in Hardy-Weinberg equilibrium, whereas that of patients was not $\left(x^{2}=7.17, P=0.027\right)$. We regenotyped the patients and found no evidence of typing errors. Patients showed lower CT and higher TT genotype frequencies when compared to those of controls. However, these changes did not reach statistical significance in the association study (Table 2).

\section{Discussion}

We have found evidence of a suggestive linkage between 12q24.32-33 markers (144-155 cM) and childhood asthma in the Japanese population. The region identified was very close to the region reported by Wilkinson et al. (1998), who investigated linkage to their unique asthma score in the English population. In the genome-wide analysis of Japanese mite-sensitive childhood asthma, the highest MLS (1.92) was observed between D12S78 and D12S86 (110-132 cM) (Yokouchi et al. 2000). This 
Table 2 Association study of the genes on chromosome 12

\begin{tabular}{|c|c|c|c|}
\hline & $\begin{array}{l}\text { Controls } \\
\text { (frequency \%) }\end{array}$ & $\begin{array}{l}\text { Asthma } \\
\text { (frequency \%) }\end{array}$ & $\begin{array}{l}\text { Significance } \\
\text { level* }\end{array}$ \\
\hline \multicolumn{4}{|c|}{ STAT6 exon 1 GT repeat } \\
\hline \multicolumn{4}{|l|}{ Allelic distribution } \\
\hline Allele 1 (13 repeat) & $77(22.4)$ & $72(31.6)$ & $P c=0.061$ \\
\hline Allele 2 (14 repeat) & $1(0.3)$ & $4(1.4)$ & $P c=0.34$ \\
\hline Allele 3 ( 15 repeat) & $233(67.7)$ & $123(53.8)$ & $P c=0.0044$ \\
\hline Allele 4 (16 repeat) & $33(9.6)$ & $29(12.7)$ & $P c>1.0$ \\
\hline Overall & $344(100.0)$ & $228(100.0)$ & $P=0.0032$ \\
\hline \multicolumn{4}{|l|}{ Genotypic distribution } \\
\hline Allele 1 /allele 1 & $14(8.1)$ & $12(10.5)$ & $P_{c}>1.0$ \\
\hline Allele 1/allele 3 & $46(26.7)$ & $41(36.5)$ & $P c=0.81$ \\
\hline Allele 1 /allele 4 & $3(1.7)$ & $7(6.1)$ & $P c=0.67$ \\
\hline Allele 2/allele 3 & $1(0.6)$ & $4(3.5)$ & $P c=0.59$ \\
\hline Allele 3/allele 3 & $81(47.1)$ & $30(26.3)$ & $P c=0.0035$ \\
\hline Allele 3/allele 4 & $24(14.0)$ & $18(15.8)$ & $P c>1.0$ \\
\hline Allele 4/allele 4 & $3(1.7)$ & $2(1.8)$ & $P c>1.0$ \\
\hline Overall & $172(100.0)$ & $114(100.0)$ & $P=0.0054$ \\
\hline \multicolumn{4}{|c|}{ NOS1 intron 2 GT repeat } \\
\hline \multicolumn{4}{|l|}{ Allelic distribution } \\
\hline Allele 1 (14 repeat) & $2(0.5)$ & $1(0.5)$ & $P c>1.0$ \\
\hline Allele 2 (15 repeat) & $11(3.0)$ & $2(0.9)$ & $P c=0.88$ \\
\hline Allele 3 (16 repeat) & $189(51.4)$ & $88(40.0)$ & $P c=0.049$ \\
\hline Allele 4 (17 repeat) & $3(0.8)$ & $7(3.2)$ & $P c=0.27$ \\
\hline Allele 5 (18 repeat) & $126(34.2)$ & $97(44.1)$ & $P c=0.11$ \\
\hline Allele 6 (19 repeat) & $37(10.1)$ & $25(11.4)$ & $P c>1.0$ \\
\hline Overall & $368(100.0)$ & $220(100.0)$ & $P=0.0082$ \\
\hline \multicolumn{4}{|c|}{ Genotypic distribution } \\
\hline Allele 1 /allele 3 & $2(1.1)$ & $1(0.9)$ & $P c>1.0$ \\
\hline Allele 2 /allele 3 & $10(5.4)$ & 2( & $P c>1.0$ \\
\hline Allele $2 /$ allele 5 & $1(0$ & 0( & $P c>1.0$ \\
\hline Allele 3 /allele 3 & $53(28.8)$ & $15(13.6)$ & $P c=0.030$ \\
\hline Allele 3 /allele 4 & $3(1.6)$ & $1(0.9)$ & $P c>1.0$ \\
\hline Allele 3/allele 5 & $50(27.2)$ & $43(39.1)$ & $P c=0.42$ \\
\hline Allele 3/allele 6 & $18(9.8)$ & $11(10.0)$ & $P c>1.0$ \\
\hline Allele $4 /$ allele 5 & $0(0.0)$ & $6(5.5)$ & $P c=0.028$ \\
\hline Allele 5/allele 5 & $28(15.2)$ & $18(16.4)$ & $P c>1.0$ \\
\hline Allele 5/allele 6 & $19(10.3)$ & $12(10.9)$ & $P c>1.0$ \\
\hline Allele $6 /$ allele 6 & $0(0.0)$ & $1(0.9)$ & $P c>1.0$ \\
\hline Overall & $184(100.0)$ & $110(100.0)$ & $P=0.0019$ \\
\hline \multicolumn{4}{|c|}{$I F N G$ intron $1 \mathrm{CA}$ repeat } \\
\hline \multicolumn{4}{|l|}{ Allelic distribution } \\
\hline Allele 1 (12 repeat) & $39(11.0)$ & $24(10.6)$ & $P c>1.0$ \\
\hline Allele 2 (13 repeat) & $209(58.7)$ & $110(48.7)$ & $P=0.12$ \\
\hline Allele 3 (14 repeat) & $6(1.7)$ & $7(3.1)$ & $P c>1.0$ \\
\hline Allele 4 (15 repeat) & $91(25.6)$ & $78(34.5)$ & $P=0.17$ \\
\hline Allele 5 (16 repeat) & $7(2.0)$ & $3(1.3)$ & $P c>1.0$ \\
\hline Allele 6 ( 17 repeat) & $0(0.0)$ & $1(0.4)$ & $P c>1.0$ \\
\hline Allele 7 (18 repeat) & $4(1.1)$ & $3(1.3)$ & $P c>1.0$ \\
\hline Overall & $356(100.0)$ & $226(100.0)$ & $P=0.12$ \\
\hline \multicolumn{4}{|l|}{ Genotypic distribution } \\
\hline Allele 1/allele 1 & $6(3.4)$ & $3(2.7)$ & $P c>1.0$ \\
\hline Allele 1 /allele 2 & $19(10.7)$ & $8(7.1)$ & $P c>1.0$ \\
\hline Allele 1 /allele 3 & $0(0.0)$ & $1(0.9)$ & $P c>1.0$ \\
\hline Allele 1 /allele 4 & $8(4.5)$ & $9(8.0)$ & $P c>1.0$ \\
\hline Allele 2 /allele 2 & $62(34.8)$ & $32(28.3)$ & $P c>1.0$ \\
\hline Allele 2/allele 3 & $3(1.7)$ & $0(0.0)$ & $P c>1.0$ \\
\hline Allele 2/allele 4 & $54(30.3)$ & $35(31.0)$ & $P c>1.0$ \\
\hline Allele 2 /allele 5 & $6(3.4)$ & $2(1.8)$ & $P c>1.0$ \\
\hline Allele 2 /allele 7 & $3(1.7)$ & $1(0.9)$ & $P c>1.0$ \\
\hline Allele 3 /allele 3 & $0(0.0)$ & $2(1.8)$ & $P c>1.0$ \\
\hline Allele 3/allele 4 & $2(1.1)$ & $1(0.9)$ & $P c>1.0$ \\
\hline Allele 3/allele 7 & $1(0.6)$ & $1(0.9)$ & $P c>1.0$ \\
\hline Allele 4/allele 4 & $13(7.3)$ & $15(13.3)$ & $P c>1.0$ \\
\hline Allele 4/allele 5 & $1(0.6)$ & $1(0.9)$ & $P c>1.0$ \\
\hline Allele $4 /$ allele 6 & $0(0.0)$ & $1(0.9)$ & $P c>1.0$ \\
\hline Allele 4/allele 7 & $0(0.0)$ & $1(0.9)$ & $P c>1.0$ \\
\hline Overall & $178(100.0)$ & $113(100.0)$ & $P=0.289$ \\
\hline
\end{tabular}

Table 2 (Continued)

\begin{tabular}{|c|c|c|c|}
\hline & $\begin{array}{l}\text { Controls } \\
\text { (frequency \%) }\end{array}$ & $\begin{array}{l}\text { Asthma } \\
\text { (frequency \%) }\end{array}$ & $\begin{array}{l}\text { Significance } \\
\text { level* }\end{array}$ \\
\hline \multicolumn{4}{|c|}{$A I C D A 465 \mathrm{C} / \mathrm{T}$} \\
\hline \multicolumn{4}{|c|}{ Allelic distribution } \\
\hline $\mathrm{C}$ & $214(58.8)$ & $119(57.8)$ & \\
\hline $\mathrm{T}$ & $150(41.2)$ & $87(42.2)$ & \\
\hline Overall & $364(100.0)$ & $206(100.0)$ & $P=0.860$ \\
\hline \multicolumn{4}{|c|}{ Genotypic distribution } \\
\hline $\mathrm{C} / \mathrm{C}$ & $63(34.6)$ & $41(39.8)$ & \\
\hline $\mathrm{C} / \mathrm{T}$ & $88(48.4)$ & $37(35.9)$ & \\
\hline $\mathrm{T} / \mathrm{T}$ & $31(17.0)$ & $25(24.3)$ & \\
\hline Overall & $182(100.0)$ & $103(100.0)$ & $P=0.099$ \\
\hline
\end{tabular}

* All significance levels were calculated by Fisher's exact methods. In allele-by-allele or genotype-by-genotype comparison, the $P$ value was corrected by multiplying the number of alleles or genotypes and expressed as $P c$

region is a little different from Wilkinson's and our peak regions. However, if we compare the region with MLS exceeding 1.0, the three regions overlap each other-our data $130-160 \mathrm{cM}$, Yokouchi et al. 110-150 cM, and Wilkinson et al. 130-160 cM. In an analysis of the Danish population, linkage with an MLS of 1.58 to atopic asthma at D12S392 $(146 \mathrm{cM})$ was reported (Haagerup et al. 2002). More recently, linkage to airway responsiveness was also suggested at $147 \mathrm{cM}$ by the Childhood Asthma Management Program (CAMP) study (Raby et al. 2003). Thus, all these studies shared a region from 140 to $150 \mathrm{cM}$. Several studies have reported linkage between asthma and the different regions of chromosome 12. The Collaborative Study on the Genetics of Asthma reported evidence of linkage to asthma of the $12 \mathrm{q} 22$ region. This study analyzed Caucasians, African Americans, and Hispanics and found a linkage peak at D12S2070 (125 cM) in Hispanics (CSGA 1997; Xu et al. 2001a). When the condition of loci of chromosome 14 was considered, this linkage peak became broader and greater and the region with an LOD score greater than 1.0 extended from $120 \mathrm{cM}$ to the telomere (Xu et al. 2001a). The region detected in Barbados families was located at 12q21.1 (90 cM), which is clearly different from those found in the Japanese and English (Barnes et al. 1999; Barnes et al. 1996). Linkage to asthma of this region has also been suggested in German and Swedish populations (Wjst et al. 1999). A suggestive linkage (MLS $=2.81$ ) for asthma was reported at a region around $\mathrm{D} 12 \mathrm{~S} 390(65 \mathrm{cM})$ in the Italian population (Malerba et al. 2000). The region was close to the region suggested by a CAMP study (Raby et al. 2003). In a founder population, Hutterites, Ober et al. (1998) suggested linkage of D12S375 (80 cM) to asthma in an earlier study, a finding not replicated in a more recent study (Ober et al. 2000). Chromosome 12 showed no evidence of linkage to asthma in Finnish families (Laitinen et al. 2001). A genome-wide study of the French population failed to detect a linkage to asthma but detected linkage to eosinophilia around the $130 \mathrm{cM}$ region (Dizier et al. 2000). There was no evidence of 
linkage to asthma-related phenotypes of chromosome 12 markers in the Chinese population, which is ethnically close to the Japanese population (Xu et al. 2001b).

In combination, the results of our and previous studies suggest that several genes located in 12q24-q33 are likely to be responsible for susceptibility to asthma. Some susceptibility genes of this region may be shared by several populations, and others may not. The MLS at the position of NOS1 $(128 \mathrm{cM})$, an association with which was detected in this study, was less than 1.0. The NOS1 locus was $20 \mathrm{cM}$ apart from the peak of the MLS. Thus, the region we detected in the present study most likely contains other asthma-susceptibility gene(s). In the $12 \mathrm{q} 24$ region, more than a hundred genes are listed in the Human Genome Map. Narrowing down the linked region by dense mapping and an intensive survey of SNPs in this region will be required to identify new susceptibility genes.

We investigated the existence of QTL for total $\operatorname{IgE}$ on chromosome 12 using asthma sib pairs. No region on chromosome 12 showed significant linkage to total IgE. Although type-2 error (false negative) could not be excluded due to the relatively small sample size, we speculate that loci in 12q22-q23 are asthma-susceptibility loci rather than QTLs that affect the total IgE level in the Japanese population. Using HE sib-pair QTL approaches, Barnes et al. (1996) reported that markers from 107 to $135 \mathrm{cM}$ showed evidence of linkage to $\log$ (total IgE) in Barbados and Amish families. Xu et al. (2000) suggested linkage (LOD score $=2.73$ ) to $\log ($ total $\mathrm{IgE})$ of the region from $P A H(108 \mathrm{cM})$ and D12S2070 $(125 \mathrm{cM})$ in the Danish population using variancecomponent linkage analysis. Analysis of total $\operatorname{IgE}$ as a dichotomous trait (high versus normal $\operatorname{IgE}$ ) was also performed by Nickel et al. (1997). They performed TDT in German children and presented evidence of association between markers located from 75 to $108 \mathrm{cM}$ and high total IgE. On the other hand, many studies have shown negative linkage for total IgE. These include studies of the Australian population by Daniels et al. (1996), the Germans by Heinzmann et al. (2000a), the Germans and Swedish by Wjst et al. (1999), the Hutterites by Ober et al. (2000), the Chinese by $\mathrm{Xu}$ et al. (2001b), the French by Dizier et al. (2000), the Finnish by Leitinen et al. (2001), the Italians by Malerba et al. (2000), and the Danish by Haagerup et al. (2002). This inconstancy suggests that the relative importance of chromosome 12 loci in controlling total IgE varies from population to population.

We detected association of STAT6 exon 1 GT repeat with Japanese childhood asthma. Our results clearly show association of the 15-repeat allele (allele 3) and asthma by allelic and genotypic distribution analyses. In Tamura's study using fewer samples than the present study, the number of heterozygote of allele 1 and allele 3 was significantly higher in patients with "allergic diseases" and that of homozygotes of allele 3 was lower in the patients with marginal statistical significance (Tamura et al. 2001). This observation was further confirmed by our present results: a change in the frequency of allele 3 homozygotes is more essential than that in the frequency of allele 1/allele 3 heterozygotes. Allele 3 appears to be a protective allele against the development of asthma in Japanese childhood asthma.

We also investigated the $2964 \mathrm{G} / \mathrm{A}$ polymorphism in the 3'-UTR that was reported to be associated with adult asthma by Gao et al. (2000b) but failed to detect association in our samples (data not shown). Similar results were reported by Deutsch et al. (2002). These observations suggest that the STAT-6 exon 1 GT repeat, but not $2964 \mathrm{G} / \mathrm{A}$, is an asthma-susceptibility polymorphism. Further study is necessary to establish whether the polymorphism is functionally relevant to disease development or only a marker for the true functional polymorphism(s).

Association of the NOS1 intron 2 GT repeat with asthma was also demonstrated in this study. Another study also describing the association of this polymorphism with asthma was carried out in the British population (Gao et al. 2000a). The 16-repeat allele of NOS1 is a protective allele against asthma development in both British and Japanese populations, suggesting that this allele represents an old protective haplotype that evoked before the division of races. It is therefore possible that this polymorphism is associated with the disease in many ethnic groups. Moreover, Grasemann et al. (2000) have shown that NOS1 exon 29 CA repeat in the 3'-UTR was associated with asthma in the US population. This is additional evidence that NOS1 is a susceptibility gene for asthma in diverse populations. Again, further study is required to conclude whether these known polymorphisms are functionally relevant to the disease development or only markers for the true functional polymorphism(s).

We were unable to detect any association between $I F N G$ and asthma in our series. Nakao et al. (2001) reported that allele frequency distribution differed between their 218 controls and 158 patients with atopic asthma in the Japanese population. Deviation of the distribution was primarily derived from the difference in frequency of allele $5(P=0.0069, P c=0.048)$. Frequencies in controls and patients of this allele were $4.8 \%$ and $1.3 \%$ respectively. In our study, the corresponding frequencies were $2.0 \%$ and $1.3 \%$ respectively. If we combine Nakao's and our data, $P$ values become 0.012 , which is not statistically significant after correction for the number of alleles $(P c=0.083)$. More subjects are required to evaluate the significance of the association. Even if the association was confirmed, allele 5 would affect less than $5 \%$ of the population, i.e., the attributable fraction of this polymorphism would be low.

Although association of $A I C D A 465 \mathrm{C} / \mathrm{T}$ (His 155His) and asthma was suggested by TDT (Noguchi et al. 2001), our case-control study failed to prove the association of this polymorphism with asthma in the same population. In allelic distribution, allele frequency was essentially the same between the patient and control groups. Genotype distribution of the patients was not in 
Hardy-Weinberg equilibrium. This did not result in significant difference in the genotype frequency between cases and controls. The data suggest that case samples were not well representative of the homogeneous population. We genotyped another set of 94 cases with this SNP. Genotypes CC, CT, and TT were 25, 50, and 19 cases respectively. Genotype frequency of the new set of patients was in Hardy-Weinberg equilibrium and not significantly different from the control value. Although we cannot exclude $A I C D A$ completely as a candidate gene for asthma, the effect of the $465 \mathrm{C} / \mathrm{T}$ polymorphism on susceptibility to asthma was not as strong as the repeat polymorphisms of STAT6 or NOS1.

In conclusion, we demonstrated that STAT6 and NOS1 loci are associated with childhood asthma in the Japanese population and showed evidence of "suggestive" linkage between region $12 \mathrm{q} 24.23-\mathrm{q} 24.33$ and asthma. This chromosome region most likely contains as yet unidentified asthma susceptibility gene(s).

Acknowledgement We thank all members of the families and volunteers who participated in this study for their kind cooperation. We also thank Ms. Kumi Kato for excellent technical assistance. This work was supported by Grants-in-Aid for Scientific Research from the Ministry of Education, Culture, Sports, Science, and Technology, Japan, and grants from the Ministry of Health, Labor, and Welfare, Japan.

\section{References}

Barnes KC, Neely JD, Duffy DL, Freidhoff LR, Breazeale DR, Schou C, Naidu RP, Levett PN, Renault B, Kucherlapati R, Iozzino S, Ehrlich E, Beaty TH, Marsh DG (1996) Linkage of asthma and total serum IgE concentration to markers on chromosome 12q: evidence from Afro-Caribbean and Caucasian populations. Genomics 37:41-50

Barnes KC, Freidhoff LR, Nickel R, Chiu YF, Juo SH, Hizawa N, Naidu RP, Ehrlich E, Duffy DL, Schou C, Levett PN, Marsh DG, Beaty TH (1999) Dense mapping of chromosome 12q13.12-q23.3 and linkage to asthma and atopy. J Allergy Clin Immunol 104:485-491

Collaborative Study on the Genetics of Asthma (CSGA) (1997) A genome-wide search for asthma susceptibility loci in ethnically diverse populations. Nat Genet 15:389-392

Daniels SE, Bhattacharrya S, James A, Leaves NI, Young A, Hill MR, Faux JA, Ryan GF, le Souef PN, Lathrop GM, Musk AW, Cookson WO (1996) A genome-wide search for quantitative trait loci underlying asthma. Nature 383:247-50

Dizier MH, Besse-Schmittler C, Guilloud-Bataille M, AnnesiMaesano I, Boussaha M, Bousquet J, Charpin D, Degioanni A, Gormand F, Grimfeld A, Hochez J, Hyne G, Lockhart A, Luillier-Lacombe M, Matran R, Meunier F, Neukirch F, Pacheco Y, Parent V, Paty E, Pin I, Pison C, Scheinmann P, Thobie N, Vervloet D, Kauffmann F (2000) Genome screen for asthma and related phenotypes in the French EGEA study. Am J Respir Crit Care Med 162:1812-1818

Duetsch G, Illig T, Loesgen S, Rohde K, Klopp N, Herbon N, Gohlke H, Altmueller J, Wjst M (2002) STAT6 as an asthma candidate gene: polymorphism-screening, association and haplotype analysis in a Caucasian sib-pair study. Hum Mol Genet 11:613-621

Ferris BG (1978) Epidemiology Standardization Project (American Thoracic Society). Am Rev Respir Dis 118:1-120
Fujii K, Matsubara Y, Akanuma J, Takahashi K, Kure S, Suzuki Y, Imaizumi M, Iinuma K, Sakatsume O, Rinaldo P, Narisawa K (2000) Mutation detection by TaqMan-allele specific amplification: application to molecular diagnosis of glycogen storage disease type Ia and medium- chain acyl-CoA dehydrogenase deficiency. Hum Mutat 15:189-196

Gao PS, Kawada H, Kasamatsu T, Mao XQ, Roberts MH, Miyamoto Y, Yoshimura M, Saitoh Y, Yasue H, Nakao K, Adra CN, Kun JF, Moro-oka S, Inoko H, Ho LP, Shirakawa T, Hopkin JM (2000a) Variants of NOS1, NOS2, and NOS3 genes in asthmatics. Biochem Biophys Res Commun 267:761-763

Gao PS, Mao XQ, Roberts MH, Arinobu Y, Akaiwa M, Enomoto T, Dake Y, Kawai M, Sasaki S, Hamasaki N, Izuhara K, Shirakawa T, Hopkin JM (2000b) Variants of STAT6 (signal transducer and activator of transcription 6) in atopic asthma. J Med Genet 37:380-382

Grasemann H, Yandava CN, Storm van's Gravesande K, Deykin A, Pillari A, Ma J, Sonna LA, Lilly C, Stampfer MJ, Israel E, Silverman EK, Drazen JM (2000) A neuronal NO synthase (NOS1) gene polymorphism is associated with asthma. Biochem Biophys Res Commun 272:391-394

Haagerup A, Bjerke T, Schiotz PO, Binderup HG, Dahl R, Kruse TA (2002) Asthma and atopy - a total genome scan for susceptibility genes. Allergy 57:680-686

Hakonarson $\mathrm{H}$, Bjornsdottir US, Halapi E, Palsson S, Adalsteinsdottir E, Gislason D, Finnbogason G, Gislason T, Kristjansson K, Arnason T, Birkisson I, Frigge ML, Kong A, Gulcher JR, Stefansson K (2002) A major susceptibility gene for asthma maps to chromosome 14q24. Am J Hum Genet $71: 483-491$

Heinzmann A, Grotherr P, Jerkic SP, Lichtenberg A, Braun S, Kruse S, Forster J, Kuehr J, Deichmann KA (2000a) Studies on linkage and association of atopy with the chromosomal region 12q13-24. Clin Exp Allergy 30:1555-1561

Heinzmann A, Mao X, Akaiwa M, Kreomer RT, Gao P, Ohshima K, Umeshita R, Abe Y, Braun S, Yamashita T, Roberts MH, Sugimoto R, Arima K, Arinobu Y, Yu B, Kruse S, Enomoto T, Dake Y, Kawai M, Shimazu S, Sasaki S, Adra CN, Kitaichi M, Inoue $\mathrm{H}$, Yamauchi K, Tomichi N, Kurimoto F, Hamasaki N, Hopkin JM, Izuhara K, Shirakawa T, Deichmann KA (2000b) Genetic variants of IL-13 signalling and human asthma and atopy. Hum Mol Genet 9:549-559

Hyden C, Pereira E (1997) Mutation screening of interferon gamma (IFN gamma) as a candidate gene for asthma. Clin Exp Allergy 27:1412-1416

Immervoll T, Loesgen S, Dutsch G, Gohlke H, Herbon N, Klugbauer S, Dempfle A, Bickeboller H, Becker-Follmann J, Ruschendorf F, Saar K, Reis A, Wichmann HE, Wjst M (2001) Fine mapping and single nucleotide polymorphism association results of candidate genes for asthma and related phenotypes. Hum Mutat 18:327-336

Ioannidis JP, Ntzani EE, Trikalinos TA, Contopoulos-Ioannidis DG (2001) Replication validity of genetic association studies. Nat Genet 29:306-309

Isidoro-García M, Rosa-Gómez S, Davila I, Lorente F, GonzalezSarmiento R (2003) Lack of association between the $7888 \mathrm{C} / \mathrm{T}$ polymorphism in the $A I D$ gene and atopy in a Spanish population. J Allergy Clin Immunol 112:460-461

Kruglyak L, Lander E (1995) Complete multipoint sib-pair analysis of qualitative and quantitative traits. Am J Hum Genet 57:439454

Kruglyak L, Daly MJ, Reeve-Daly MP, Lander ES (1996) Parametric and nonparametric linkage analysis: a unified multipoint approach. Am J Hum Genet 58:1347-1363

Laitinen T, Daly MJ, Rioux JD, Kauppi P, Laprise C, Petays T, Green T, Cargill M, Haahtela T, Lander ES, Laitinen LA, Hudson TJ, Kere J (2001) A susceptibility locus for asthmarelated traits on chromosome 7 revealed by genome-wide scan in a founder population. Nat Genet 28:87-91 
Lander E, Kruglyak L (1995) Genetic dissection of complex traits: guidelines for interpreting and reporting linkage results. Nat Genet 11:241-247

Malerba G, Lauciello MC, Scherpbier T, Trabetti E, Galavotti R, Cusin V, Pescollderungg L, Zanoni G, Martinati LC, Boner AL, Levitt RC, Pignatti PF (2000) Linkage analysis of chromosome 12 markers in Italian families with atopic asthmatic children. Am J Respir Crit Care Med 162:1587-1590

Mao XQ, Shirakawa T, Yoshikawa T, Yoshikawa K, Kawai M, Sasaki S, Enomoto T, Hashimoto T, Furuyama J, Hopkin JM, Morimoto K (1996) Association between genetic variants of mast-cell chymase and eczema. Lancet 348:581-583

Nakao F, Ihara K, Kusuhara K, Sasaki Y, Kinukawa N, Takabayashi A, Nishima S, Hara T (2001) Association of IFN-gamma and IFN regulatory factor 1 polymorphisms with childhood atopic asthma. J Allergy Clin Immunol 107:499-504

Nickel R, Wahn U, Hizawa N, Maestri N, Duffy DL, Barnes KC, Beyer K, Forster J, Bergmann R, Zepp F, Wahn V, Marsh DG (1997) Evidence for linkage of chromosome 12q15-q24.1 markers to high total serum IgE concentrations in children of the German Multicenter Allergy Study. Genomics 46:159-162

Noguchi E, Shibasaki M, Inudou M, Kamioka M, Yokouchi Y, Yamakawa-Kobayashi K, Hamaguchi H, Matsui A, Arinami T (2001) Association between a new polymorphism in the activation-induced cytidine deaminase gene and atopic asthma and the regulation of total serum IgE levels. J Allergy Clin Immunol 108:382-386

Ober C, Cox NJ, Abney M, Di Rienzo A, Lander ES, Changyaleket B, Gidley H, Kurtz B, Lee J, Nance M, Pettersson A, Prescott J, Richardson A, Schlenker E, Summerhill E, Willadsen S, Parry R (1998) Genome-wide search for asthma susceptibility loci in a founder population. The Collaborative Study on the Genetics of Asthma. Hum Mol Genet 7:1393-1398

Ober C, Tsalenko A, Parry R, Cox NJ (2000) A second-generation genomewide screen for asthma-susceptibility alleles in a founder population. Am J Hum Genet 67:1154-1162

O'Connell JR, Weeks DE (1998) PedCheck: a program for identification of genotype incompatibilities in linkage analysis. Am J Hum Genet 63:259-266
Raby BA, Silverman EK, Lazarus R, Lange C, Kwiatkowski DJ, Weiss ST (2003) Chromosome 12q harbors multiple genetic loci related to asthma and asthma-related phenotypes. Hum Mol Genet 12:1973-1979

Tamura K, Arakawa H, Suzuki M, Kobayashi Y, Mochizuki H, Kato M, Tokuyama K, Morikawa A (2001) Novel dinucleotide repeat polymorphism in the first exon of the STAT-6 gene is associated with allergic diseases. Clin Exp Allergy 31:1509-1514

Wilkinson J, Grimley S, Collins A, Thomas NS, Holgate ST, Morton N (1998) Linkage of asthma to markers on chromosome 12 in a sample of 240 families using quantitative phenotype scores. Genomics 53:251-259

Wjst M, Fischer G, Immervoll T, Jung M, Saar K, Rueschendorf F, Reis A, Ulbrecht M, Gomolka M, Weiss EH, Jaeger L, Nickel R, Richter K, Kjellman NI, Griese M, von Berg A, Gappa M, Riedel F, Boehle M, van Koningsbruggen S, Schoberth P, Szczepanski R, Dorsch W, Silbermann M, Wichmann HE, et al. (1999) A genome-wide search for linkage to asthma. German Asthma Genetics Group. Genomics 58:1-8

Xu J, Postma DS, Howard TD, Koppelman GH, Zheng SL, Stine OC, Bleecker ER, Meyers a D (2000) Major genes regulating total serum immunoglobulin E levels in families with asthma. Am J Hum Genet 67:1163-1173

Xu J, Meyers DA, Ober C, Blumenthal MN, Mellen B, Barnes KC, King RA, Lester LA, Howard TD, Solway J, Langefeld CD, Beaty TH, Rich SS, Bleecker ER, Cox NJ (2001a) Genomewide screen and identification of gene-gene interactions for asthmasusceptibility loci in three U.S. populations: collaborative study on the genetics of asthma. Am J Hum Genet 68:1437-1446

Xu X, Fang Z, Wang B, Chen C, Guang W, Jin Y, Yang J, Lewitzky S, Aelony A, Parker A, Meyer J, Weiss ST (2001b) A genomewide search for quantitative-trait loci underlying asthma. Am J Hum Genet 69:1271-1277

Yokouchi Y, Nukaga Y, Shibasaki M, Noguchi E, Kimura K, Ito S, Nishihara M, Yamakawa-Kobayashi K, Takeda K, Imoto N, Ichikawa K, Matsui A, Hamaguchi H, Arinami T (2000) Significant evidence for linkage of mite-sensitive childhood asthma to chromosome 5q31-q33 near the interleukin $12 \mathrm{~B}$ locus by a genome-wide search in Japanese families. Genomics $66: 152-160$ 